\title{
Oral granular cell tumor: a study of twelve cases in a Brazilian population
}

\author{
Fabrício Bitu Sousa ${ }^{1}$, Rafael Lima Verde Osterne ${ }^{2}$, Renata Galvão de Matos Brito ${ }^{3}$, Ana Paula Negreiros \\ Nunes Alves ${ }^{4}$, Eduardo Costa Studart Soares ${ }^{5}$, Fábio Wildson Gurgel Costa ${ }^{6}$
}

\footnotetext{
${ }^{1} \mathrm{PhD}$ associated Professor, Department of Oral Pathology and Stomatology, Federal University of Ceara (Brazil).

${ }^{2}$ MSc associated Professor, Department of Medicine, Morfofunctional Laboratory, University of Fortaleza (Brazil)

${ }^{3}$ Master in Dentistry, Federal University of Ceara. Dental surgeon in Private Practice.

${ }^{4} \mathrm{PhD}$ associated Professor, Department of Oral Pathology and Stomatology, Federal University of Ceara (Brazil)

${ }^{5} \mathrm{MSc}, \mathrm{PhD}$ associated Professor, Department of Oral and Maxillofacial Surgery, Federal University of Ceara

${ }^{6}$ MSc Associated Professor, Department of Stomatology, Federal University of Ceara, (Sobral Campus)
}

\author{
Correspondence: \\ Laboratório Morfofuncional (LMF), \\ Curso de Medicina, \\ Universidade de Fortaleza; \\ Av. Washington Soareas, 1321, Edson Queiroz; \\ CEP 60.811-905, Fortaleza-Ce, Brazil. \\ E-mail: rlimaverde@unifor.br
}

Received: 19/07/2010

Accepted: 01/09/2010
Sousa FB, Osterne RLV, Matos Brito RG, Alves APNN, Soares ECS, Costa FWG. Oral granular cell tumor: a study of twelve cases in a Brazilian population. J Clin Exp Dent. 2010;2(4):e178-82.

http://www.medicinaoral.com/odo/volumenes/v2i4/jcedv2i4p178.pdf

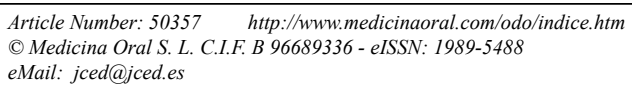

\begin{abstract}
Objectives: Analyze clinic and epidemiological aspects of all Oral Granular cell tumor (GCT) during a 5-year period in a Brazilian population. Study design: clinical and treatment outcome data of patients with oral GCT seen at the Division of Stomatology, School of Dentistry, Federal University of Ceara, Brazil, between January 2001 and December 2005 were reviewed. Results: during the analyzed period, 6231 oral lesions were collected from files of different anatomo-pathology laboratories situated in the state of Ceara, Brazil. Of all cases, only 12 of GCT were diagnosed. The lesion was more common in female patients, with a mean age of 40.8 years, occurring mainly in tongue. Conclusion: Oral GCT is a rare and infrequent lesion in this population, and affects more female in the third, fourth a fifth decade of life. Clinical significance: Although it is a rare occurrence in the oral cavity, the clinician must know about its occurrence and should include GCT in the differential diagnose of certain lesions especially when situated in tongue.
\end{abstract}

Key words: granular cell tumor, Abrikosoff tumor, tongue, oral neoplasms. 


\section{Introduction}

Granular cell tumor (GCT) or Abrikosoff's tumor was firstly described in 1926 and it is a rare benign soft tissue lesion that can occur in any part of the body, but over half of the cases are in the head and neck areas, and the tongue is the most common site $(1,2)$. Due to the apparent association between GCT and skeletal muscle (3), it has also been known as granular cell myoblastoma and granulocellular rabdomyoma (4). Although the histogenesis of the GCT has not been established conclusively, immunohistochemical and ultrastructural studies support the origin of the lesion from Schwann cells $(5,6)$.

The GCT can be clinically and/or histopatologically similar to others conditions presented in the oral cavity such as congenital granular cell epulis, primitive polypoid granullar cell tumor, minor salivary gland tumors, amyloidosis, and lipoma (7-10). However, a few studies have discussed about the differential diagnosis.

Oral examination usually reveals a solitary painless tumor, although cases of multiple lesions have been reported affecting posterior lateral zone and dorsum of the tongue (4). It can arise in any age, with a peak between 40 and 60 years. About the gender, some studies have demonstrated a female predilection $(2,11)$. In the present manuscript, the data of all cases of oral GCT seen at a 5-year-period study in a Brazilian population was reviewed. In addition, clinical aspects and differential diagnosis were discussed.

\section{Materials and Methods}

The clinical and treatment outcome data of patients with oral GCT seen at the Division of Stomatology, School of Dentistry, Federal University of Ceara, Brazil, between January 2001 and December 2005 were reviewed. In addition, data from five anatomopathological laboratories, three private and two public, all situated in Fortaleza, Ceará, Brazil, were included in this study. These cases were analyzed retrospectively, and data regarding sex, race, age, anatomical site and histopathological diagnosis were registered. Twelve cases of oral GCT were diagnosed in this period.

\section{Results}

Sex and age

Oral GCT was identified in $12(0.19 \%)$ cases out of 6132 lesions of the anatomopathological laboratories accessed during the 5-year period (Data summarized on table 1). The study group consisted of 1 male and 11 female with a mean age of 40.8 years (range: 21-74). The mean age of females was 41.6 years.

\section{Clinical data}

In the present study, all patients presented painless swelling. The lesions were described as solitary, circumscribed and firm with normal to yellowish color. Out of the 12 oral GCT, 11 were located in tongue and 1 on the floor of the mouth. Among tongue lesions, 9 cases occurred on lateral border, 1 on the dorsal surface and 1 on anterior region (Fig. 1).

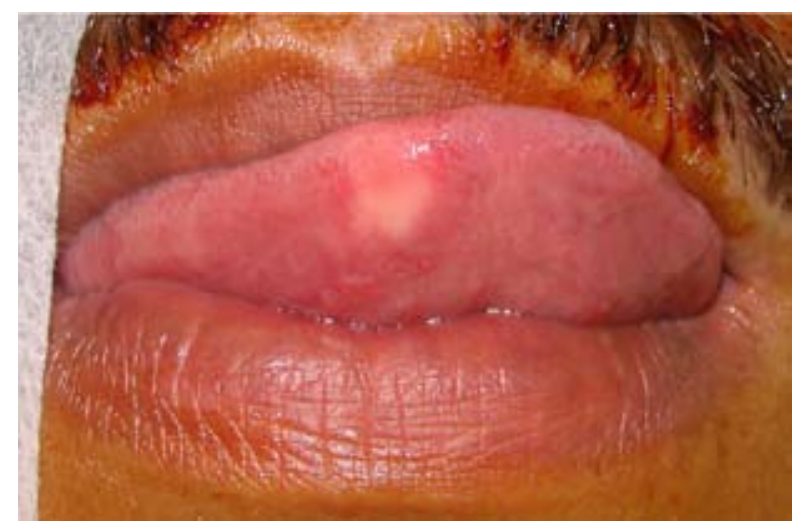

Fig. 1. Clinical appearance of a yellow patch on the anterior aspect of the tongue.

\section{Treatment}

The treatment performed in all cases was a conservative surgical excision at the time of biopsy, although in 1 case the procedure was developed in two steps (Incisional biopsy followed by definitive surgical procedure).

\section{Discussion}

Granular cells can be seen in a wide variety of uncommon neoplasms including granular cell tumor, congeni-

\begin{tabular}{ccccc}
\hline Case & Sex & Age & Location & Treatment \\
\hline 1 & Female & 49 & Floor of mouth & Excisional biopsy \\
2 & Female & 74 & Lateral surface of tongue & Excisional biopsy \\
3 & Female & 38 & Lateral surface of tongue & Excisional biopsy \\
4 & Female & 24 & Lateral surface of tongue & Excisional biopsy \\
5 & Female & 64 & Lateral surface of tongue & Excisional biopsy \\
6 & Female & 43 & Dorsal surface of tongue & Excisional biopsy \\
7 & Female & 35 & Lateral surface of tongue & Excisional biopsy biopsy \\
8 & Female & 21 & Lateral surface of tongue & Excisional biopsy \\
9 & Female & 43 & Lateral surface of tongue & Excisional biopsy \\
10 & Female & 31 & Anterior tongue & Incisional biopsy followed by surgical excision \\
11 & Male & 31 & Lateral surface of tongue & Excisional biopsy \\
12 & Female & 36 & Lateral surface of tongue &
\end{tabular}

Table 1. Clinical features and treatment outcome for 12 cases of oral GCT 
tal granular cell epulis, primitive polypoid granular cell tumor, granular cell ameloblastoma, central granular cell odontogenic fibroma, granular cells in odontogenic cysts and lichen planus $(5,7,10)$. Granular cell changes can result from the cytoplasmic accumulation of various types of material, and the cell particularly prone to undergo the granular cell change is the Schwann cell (12).

The Abrikosoff's tumor has been associated to skeletal muscle, histiocytes, fibroblasts, myoepithelium, and nerve cell connective tissue origin (4), but the histiogenesis of the GCT has not been conclusively established yet. However, according to Junqueira et al (5) the imunohistochemical profile of GCT suggests a neural and/or neuroectodermal origin of granular cells. This theory supports the fact that lesions are a consequence of altered cellular metabolism of Schwann cells or their precursors (1). This hypothesis is based on its positivity to S100, neurone-especific enolase, glycoprotein and leu-7, and electron microscopy studies, which shows a continuous basal layer around the cells, reminiscent from perineurium, and the presence of structures compatible with myelin, inside presumably in autophagic lisosomes $(3,13)$.

As previously reported in literature, the reviewed cases of GCT occurred as solitary lesions, presenting a higher prevalence in females, affecting patients between 21 to 74 years old, mean age of 41,8 years old. GCT is usually a solitary slow growth painless, but cases of multiple lesions have been reported (4). It can arise in all age groups, with a peak between fourth and sixth decades of life. Women are more affected than men, with a female:male ratio of 2:1 (11). The lesion typically presents as a smooth, sessile mucosal swelling with a firm texture, the mucosal color varies from normal or slightly pale to yellowish. Oral lesions have been mostly described affecting the tongue on dorsum and lateral zone of posterior region. In the eleven analyzed cases, nine occurred on these regions. We also described an unusual tongue lesion occurring in anterior ventral surface in a male patient. GCT has also been described affecting the buccal mucosa, palate, gingival, and floor of the mouth $(1,2,4,5,14-17)$.

Microscopically (Fig. 2), granular cell tumor exhibit round or polygonal cells with small excentrically placed nuclei and abundant pale eosinophilic granular cytoplasm $(1,15,16)$. The cells are usually arranged in unencapsulated sheets, but may also be found in cords and nests. The cell borders are generally indistinct giving rise to a syncytial appearance. Apparently, when there is a transformation from normal adjacent skeletal muscle fibers to granular tumor cells a proposition of a muscular origin has been suggested (11). In lesions involving tongue, the pseudoepitheliomatous hyperplasia may be so pronounced that it has been misinterpreted as squamous cell carcinoma $(6,18)$.

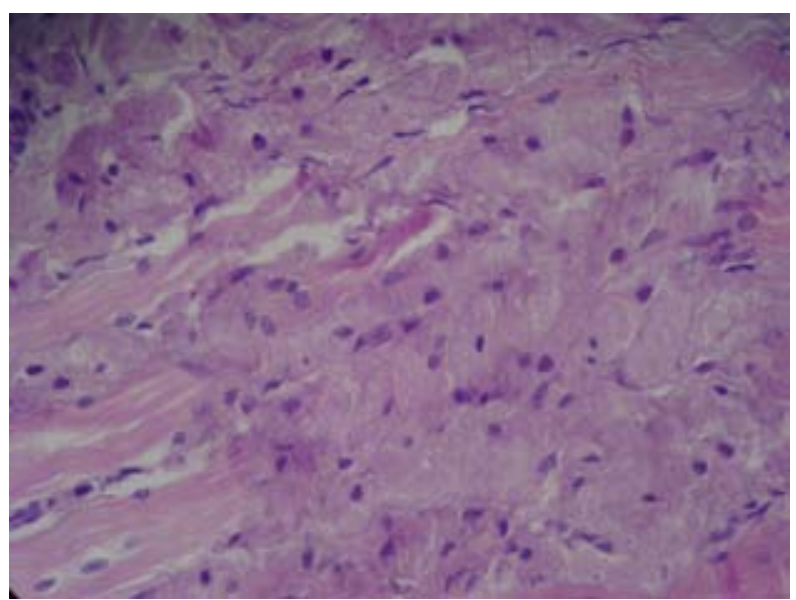

Fig. 2. Photomicrography showing an abundant densely filled round to oval cells with regular nuclei and granular eosinophilic cytoplasm (H-E stain, x400).

The immunoprofile of the GCT shows a strong and uniform positivity for S-100 protein $(2,19)$. S-100 immunoreactivity (Fig. 3) is the most widely used marker for identification of the granular cells in GCT, other S-100 positive tumor types which can be presented in the differential diagnosis includes selected histiocytic proliferations, poorly diferentiated carcinomas, peripheral nerve sheath tumors, tumors that contain myoepithelial cells, and melanoma. In a study with 42 oral GCT, all cases were found to be positive for S-100 (19). CD-68 is another traditionally used marker for identifications of GCT $(2,19)$. Positive reactions for CD-68 can be found in cells of Schwannian lineage, but also in macrophage and occasionally in fibroblastic lineage (19). Cells can also express neurone-specific enolase, calretinin,

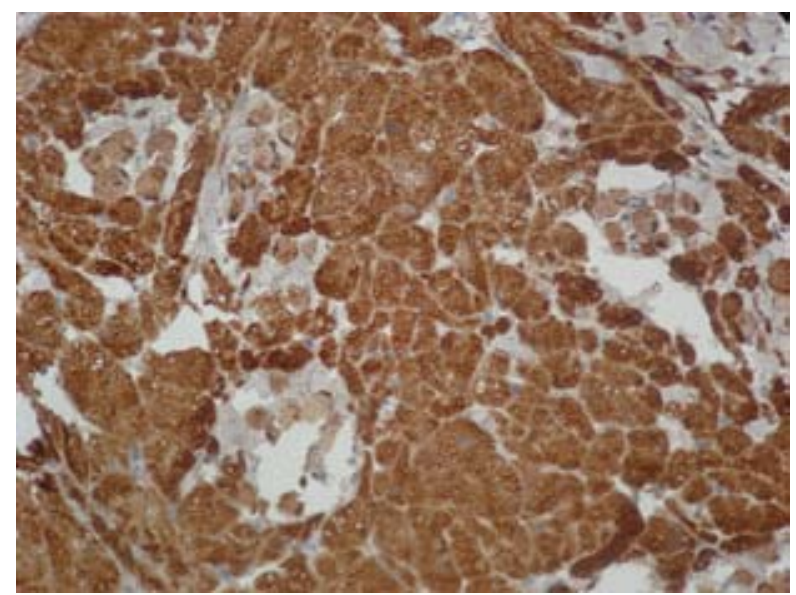

Fig. 3. Immunoprofile showing a strong and uniform positivity for S-100 protein; original magnification $x 400$.

inhibin-alpha and PGP 9.5, but no reactivity for smooth muscle actin (19).

The differential diagnosis for GCT is extensive and should include congenital granular cell epulis (7), primitive polypoid granullar cell tumor (10), amyloidosis (8), e180 
conditions that could be included are colloid milium (21), sarcoidosis (22), aspergillosis (23), and UrbachWiethe disease (24).

Congenital granular cell epulis (CGCE) and primitive polypoid granular cell tumor (PGCT) are histopatologically the most difficult differential diagnosis to distinguish from GCT $(7,10)$. The CGCE is a benign lesion arising from the alveolar ridges of newborn, usually presenting as a solitary fibroma-like lesion near the midline. Although the histological features of the GCT and the CGCE are similar, the pseudoepitheliomatous hyperplasia does not occur in CGCE. Also, the lack of immunoreactivity with S-100 suggests that the lesion is derived from a different GCT cell line. The PGCT is a lesion that is histologically similar to GCT, but show expansive growth, cellular atypia and negative staining for S-100 (17).

Amyloidosis is a clinical entity with variable presentation, depending on the organs involved. In tongue, typically presents as yellow nodules or raised white lesions and results in macroglossia, manifested by increased tongue volume, tongue protrusion beyond the alveolar ridge, speech impairment, and dysphagia. Amyloid of the tongue is usually secondary to primary amyloidosis with plasma cell dyscrasia. Criteria for diagnosis include eosinophilic extracellular deposits of protein fibrils that exhibit apple-green birefringence on polarized light microscopy when stained with Congo red (8).

An asymptomatic circumscribed tongue mass could represent a benign connective tissue tumor. The yellowish color of the present lesion resembles a lipoma, which can appear as a smooth-surfaced, sessile, or pedunculated tumor. The consistency of lipoma is usually soft to fluctuant and histologically is composed by adipocytes that are subdivided into lobules by septet of fibrous connective (9).

Although the tongue is an unusual location for minor salivary gland tumors, theses lesions may be included in the differential diagnosis due to the location, and epidemiological characteristics (25). Also, minor salivary gland tumors may produce a pale to yellowish surface, but the singular histopathological characteristics of these tumors differ than from the oral GCT $(15,20)$.

Colloid milium is a rare cutaneous degenerative disorder characterized by the presence of multiple dome-shaped amber- or flesh-colored papules developed on sun-exposed skin. The rare oral lesions are single or multiple yellowish-brows nodules involving tongue and lower lip. Microscopic examination reveals proliferations of sheets of homogeneous relatively acelular glassy eosinophilic amyloid-like material, with no green birefringence under polarized light after Congo red staining, and thus it does not show the classic features of GCT or amyloidosis (21).

Sarcoidosis and aspergillosis in the oral cavity are ex- tremely rare. Granulomatous lesion of sarcoidosis has been reported as yellowish-brown plaque in tongue (22), but a systemic explore, thoracic x-ray and biopsy may be helpful in differential diagnosis. In addition, Bor et al. (23) analyzed an acute lymphoblastic leukemia, in a 5-year-old boy, with probable pulmonary aspergillosis, who developed a hard, protuberant, white-yellow and aggressive elongated lesion on the left side of his tongue during a febrile agranulocytopenic episode.

Urbach-Wiethe disease, although rare, is another lesion that may be presented in the oral cavity as a solitary lesion with a yellowish appearance. It is a lipoid proteinosis, recessively inherited disorder, characterized by infiltration of a hyalin-like material in skin, mucous membranes, brain and other internal organs. The cutaneous lesions appeared early in childhood soon after the development of hoarseness and were located along the margin of both eyelids and on the upper lip on a beaded arrangement. Hyperkeratotic plaques were also found on the elbows and in tongue as a white to yellowish lesions (24).

GCT is benign, although in $1 \%$ to $3 \%$ of cases, a malignant development can occur. The malignancy of GCT is largely suggested by its rapid growth, the broad dimensions $(>4 \mathrm{~cm})$, and the presence of necrotic and hemorrhagic areas, whereas histologically it shows a high mitotic index and a cellular/nuclear pleomorphism. In the cases of malignant degeneration, the tissues most affected by metastasis are lymph nodes, bony tissue, peripheral nerves, peritoneal cavity, and lungs (1).

The treatment, exclusively surgical, consists of local excision with the overhanging mucosa. In $15 \%$ of cases, local recurrence is possible in the incomplete excision of the lesion, whereas relapse occurs in $1 \%$ to $3 \%$ of cases. Radiotherapy and chemotherapy are not indicated because of the resistance of the tumor and potential carcinogenic effects (11). Although complete surgical excision generally leads to a cure, long-term follow up is recommended. It is advised for the patients about the returns at periodic intervals due to possibility of recurrences and to assess for malignant transformation.

\section{Conclusion}

Oral GCT is rare and infrequent lesion in this population, and even more rare in male patient. This benign neoplasm manly effect females, in the third to fifth decades of life. There is a large predilection for tongue.

Clinical relevance

GCT is an uncommon entity, and oral GCT, even though rare, must be included by general dentists as part of the differential diagnosis of lesions that arise in the oral cavity, especially when their locations are the tongue or floor of the mouth. 


\section{References}

1. Becelli R, Perugini M, Gasparini G, Cassoni A, Fabiani F. Abrikossoff's tumor. J Craniofac Surg. 2001; 12:78-81.

2. Garcia-Rejas RA, Sampaio-Campos M, Rodriguez-Gonzalez-Cortes A, Dos Santos-Pinto-Júnior D, Orsini-Machado de Sousa SC. The neural histogenetic origin of the oral granular cell tumor: An immunohistochemical evidence. Med Oral Patol Oral Cir Bucal. 2010 Jun 1. [Epub ahead of print]

3. Collins BM, Jones AC. Multiple granular cell tumors of the oral cavity: report of a case and review of the literature. J Oral Maxillofac Surg. 1995; 53:707-11.

4. Budiño-Carbonero S, Navarro-Vergara P, Rodríguez-Ruiz JA, Modelo-Sánchez A, Torres-Garzón L, Rendón-Infante JI et al. Granular cell tumors: review of the parameters determining possible malignancy. Med Oral. 2003; 8:294-8.

5. Junquera LM, de Vicente JC, Vega JA, Losa JL, Albertos JM, López-Arranz JS. Granular-cell tumours: an immunohistochemical study. Br J Oral Maxillofac Surg. 1997; 35:180-4.

6. Lassaletta L, Alonso S, Ballestín C, Martínez-Tello FJ, Alvarez-Vicent JJ. Immunoreactivity in granular cell tumours of the larynx. Auris Nasus Larynx. 1999; 26:305-10.

7. Basile JR, Woo SB. Polypoid S-100-negative granular cell tumor of the oral cavity: a case report and review of literature. Oral Surg Oral Med Oral Pathol Oral Radiol Endod. 2003; 96:70-6.

8. Koloktronis A, Chatzigiannis I, Paloukidou N. Oral involvement in a case of AA amyloidosis. Oral Dis. 2003; 9:269-72.

9. Chidzonga MM, Mahomva L, Marimo C. Gigantic tongue lipoma: a case report. Med Oral Patol Oral Cir Bucal. 2006; 11:E437-9.

10. Silva GC, Vieira TC, Vieira JC, Martins CR, Silva EC. Congenital granular cell tumor (congenital epulis): a lesion of multidisciplinary interest. Med Oral Patol Oral Cir Bucal. 2007; 12:E428-30.

11. Nagaraj PB, Ongole R, Bhujanga-Rao BR. Granular cell tumor of the tongue in a 6-year-old girl--a case report. Med Oral Patol Oral Cir Bucal. 2006; 11:E162-4.

12. Rosai J. The appearance, nature, and significance of cytoplasmic accumulations, as exemplified by the granular cell change. Int J Surg Pathol. 2006; 14:109-11.

13. Burton DM, Heffner DK, Patow CA. Granular cell tumors of the trachea. Laryngoscope. 1992; 102:807-13.

14. Zahid L, Cariappa KM. Granular cell tumor of buccal mucosa--a case report. Int J Oral Maxillofac Surg. 1996; 25:134-5.

15. Eguia A, Uribarri A, Gay Escoda C, Crovetto MA, Martinez-Conde R, Aguirre JM. Granular cell tumor: report of 8 intraoral cases. Med Oral Patol Oral Cir Bucal. 2006 11:E425-8.

16. Tosios K, Rallis G, Vallianatou D, Vlachodimitropoulos D. Yellowwhite tumor on the floor of the mouth. Oral Surg Oral Med Oral Pathol Oral Radiol Endod. 2006; 101:701-4.

17. Lerman M, Freedman PD. Nonneural granular cell tumor of the oral cavity: a case report and review of the literature. Oral Surg Oral Med Oral Pathol Oral Radiol Endod. 2007; 103:382-4.

18. Abu-Eid R, Landini G. Morphometrical differences between pseudo-epitheliomatous hyperplasia in granular cell tumours and squamous cell carcinomas. Histopathology. 2006; 48:407-16.

19. Vered M, Carpenter WM, Buchner A. Granular cell tumor of the oral cavity: updated immunohistochemical profile. J Oral Pathol Med. 2009; 38:150-9.

20. Matsumoto Y. Lipofuscin pigmentation in pleomorphic adenoma of the palate. Oral Surg Oral Med Oral Pathol Oral Radiol Endod. 2001; 92:299-302.

21. Ojha J, Bhattacharyya I, Islam NM, Wong F, Cohen DM. Colloid milium of the oral cavity: a rare presentation. Oral Surg Oral Med Oral Pathol Oral Radiol Endod. 2008; 105:e34-8.

22. Marcoval J, Mañá J. Specific (granulomatous) oral lesions of sarcoidosis: Report of two cases. Med Oral Patol Oral Cir Bucal. 2010 May 1;15(3):e456-8.

23. Bor O, Cagri Dinleyici E, Kiraz N, Dundar E, Akdeniz Akgun N. Successful treatment of tongue aspergillosis caused by Aspergillus flavus with liposomal amphotericin B in a child with acute lymphoblastic leukemia. Med Mycol. 2006; 44:767-70.
24. Cole JA, Novosel TA, Williams JV. Pocklike scarring and sublingual papules in a child. Lipoid proteinosis. Arch Dermatol. 2008; 144:1383-8.

25. Dhanuthai K, Boonadulyarat M, Jaengjongdee T, Jiruedee K. A clinico-pathologic study of 311 intra-oral salivary gland tumors in Thais. J Oral Pathol Med. 2009 Jul;38(6):495-500. 